\title{
ISOLATION OF PSEUDOMONAS AERUGINOSA STRAINS FROM DENTAL OFFICE ENVIRONMENTS AND UNITS IN BARRETOS, STATE OF SÃO PAULO, BRAZIL, AND ANALYSIS OF THEIR SUSCEPTIBILITY TO ANTIMICROBIAL DRUGS
}

\author{
Ana Claudia de Oliveira ${ }^{1}$; Renato Pariz Maluta ${ }^{1}$; Ariel Eurides Stella ${ }^{1}$; Everlon Cid Rigobelo ${ }^{2}$; \\ José Moacir Marin³; Fernando Antonio de Ávila ${ }^{4 *}$
}

${ }^{1}$ Programa de Microbiologia, Faculdade de Ciências Agrárias e Veterinárias, Jaboticabal, Universidade Estadual Paulista, Jaboticabal, SP, Brasil; ${ }^{2}$ Unidade Diferenciada de Dracena, Universidade Estadual Paulista, Dracena, SP, Brasil; ${ }^{3}$ Departamento de Morfologia, Estomatologia e Fisiologia, Faculdade de Odontologia de Ribeirão Preto, Universidade de São Paulo, Ribeirão

Preto, SP, Brasil; ${ }^{4}$ Departamento de Patologia, Faculdade de Ciências Agrárias e Veterinárias, Jaboticabal, Universidade Estadual Paulista, Jaboticabal, SP, Brasil.

Submitted: October 05, 2007; Returned to authors for corrections: February 22, 2008; Approved: July 13, 2008.

\begin{abstract}
A wide variety of opportunistic pathogens has been detected in the tubing supplying water to odontological equipment, in special in the biofilm lining of these tubes. Among these pathogens, Pseudomonas aeruginosa, one of the leading causes of nosocomial infections, is frequently found in water lines supplying dental units. In the present work, 160 samples of water, and 200 fomite samples from forty dental units were collected in the city of Barretos, State of São Paulo, Brazil and evaluated between January and July, 2005. Seventy-six P. aeruginosa strains, isolated from the dental environment (5 strains) and water system (71 strains), were tested for susceptibility to six antimicrobial drugs most frequently used against $P$. aeruginosa infections. Susceptibility to ciprofloxacin, followed by meropenem was the predominant profile. The need for effective means of reducing the microbial burden within dental unit water lines is emphasized, and the risk of exposure and cross-infection in dental practice, in special when caused by opportunistic pathogens like $P$. aeruginosa, are highlighted.
\end{abstract}

Key-words: Pseudomonas aeruginosa, dental units, water lines, opportunistic pathogens, antimicrobial resistance, biofilms.

\section{INTRODUCTION}

Pseudomonas aeruginosa is essentially a free-living bacterium that occasionally can be found in the intestinal tract, and is now considered a major cause of opportunistic hospital infections, responsible for $9-11 \%$ of all nosocomial infections yearly reported in the United States. It causes significant morbidity and mortality in immunocompromised subjects showing burns, cystic fibrosis, chronic bronchitis and cancer. It is also often found in wet environments (sinks, disinfectants, humidifiers, water baths and suction apparatuses of hospitals), freely multiplying and transferring to compromised patient (5).
Dental units are focal point of dental clinics. Hand pieces (high-speed drills), air/water syringes, ultrasonic scalers, and prophy-angles are connected to dental units by a network of small-bore plastic tubing carrying water and air to activate or cool instruments. Potable municipal water normally supplies these units, although sometimes independent distilled or sterile water reservoirs are employed. It has long been known that the water collected at the outflow of dental unit waterlines (DUWL) is densely populated, bacterial counts ranging from a few thousand to as high as $10^{6}$ colony forming units ( $\left.\mathrm{cfu}\right) / \mathrm{ml}$ $(4,7,14)$, which can reflect the colonization of waterlines by biofilms $(23,31)$.

*Corresponding Author. Mailing address: Departamento de Patologia, Faculdade de Ciências Agrárias e Veterinárias de Jaboticabal, Universidade Estadual Paulista, Via de Acesso Prof. Paulo Donato Castellane, s/n, 14884-900, Jaboticabal, SP, Brasil. 
The observation that potentially pathogenic microorganisms, like $P$. aeruginosa, may be present in water used to perform intraoral treatment, has led to some concern (23). P. aeruginosa has been proven to be responsible for infections in immunocompromised patients treated at units harboring these organisms (14) and Costerton et al. (10) have presented evidence that exposure to fragments of biofilm dispersed by aerosols may constitute a serious insult to the pulmonary system of human beings; P. aeruginosa has been found in $24 \%$ of the waterlines analyzed by Barbeau et al. (4).

It is difficult to treat infections caused by $P$. aeruginosa due to their resistance to many commonly used disinfectants and antibiotics, like first and second generation cephalosporins $(9,28)$. In general, only advanced generation beta-lactam antibiotics, aminoglycosides and fluoroquinolones have been shown to be useful in this regard (5).

Most studies on DUWL have been carried out in dental teaching hospitals; risks occurring during general dental practice (private dental clinics) have not been fully described, in special in relation to multidrug-resistant $P$. aeruginos $a$ strains. The aim of the present study was to analyze the antimicrobial susceptibility of $P$. aeruginos $a$ strains isolated from dental clinic environments and waterlines, as well to check the quality of the water employed in these units.

\section{MATERIALAND METHODS}

\section{Sampling}

One hundred and sixty samples of water (from taps, ground tanks, bottles, high-speed drills and air/water syringes), and two hundred samples of the dental clinic environment (head lights, dental chairs, air/water syringes, high and low-speed drills) were colected from forty dental clinics of the city of Barretos, São Paulo, Brazil, during January to July, 2005. The dental clinics examined were chosen at random among major city areas and comprised 15 dental care aid centers, 8 municipal clinics of the public health system, and 17 private dental care clinics. The selected units were fed with tap water, ground tank water or bottled filtered water.

Water samples were taken from each chosen site, and $250 \mathrm{ml}$ were placed in sterilized flasks; a solution of sodium thiosulfate to a final concentration of $10 \mathrm{ml} / \mathrm{L}$ was added to inactivate remaining disinfectants. Samples were placed in a box, kept at $4-8^{\circ} \mathrm{C}$ and delivered to the laboratory within $3 \mathrm{~h}$. Environmental samples were taken using swabs moistened with $3 \mathrm{ml}$ of Brain Heart Infusion (BHI), and passed over the surface to be analyzed. After collection, tubes with the swabs were placed in a cooled box and stored in the laboratory.

\section{Bacterial isolation and identification}

The BHI tubes containing the swabs were incubated at $37^{\circ} \mathrm{C}$ for 24h. The swabs were depleted on Pseudomonas Agar P
(PAP) and Pseudomonas Agar F (PAF) plates and incubated at $37^{\circ} \mathrm{C}$ for $24-48 \mathrm{~h}$.

All water samples were filtered through $0.55 \mu \mathrm{m}$ (cellulose nitrate) analytical test filters (Fisher Scientific, Ireland), in order to collect the waterborne microorganisms. Membranes were removed from the funnel using sterile forceps and deposited on PAP or PAF plates and incubated at $37^{\circ} \mathrm{C}$ for $24-48$ h. From each plate showing bacterial growth, three colonies presenting characteristics compatible with the Pseudomonas genus were randomly selected, stained by the Gram method, inoculated in Triple Sugar Iron (TSI) tubes and incubated at $37^{\circ} \mathrm{C}$ for $24 \mathrm{~h}$. Isolates were submitted to identification by acetamide alkalinization, reduction from nitrate to nitrite and motility observation (2).

\section{Counting of viable bacteria}

Total viable bacteria counts (TVC) were performed on decimal dilutions of the water samples, and considered to be definitive measurements of the total microbial contamination of the water passing through the dental unit water systems (DUWS). Samples were filtered as described above, and the collected cellulose nitrate filters deposited on Pseudomonas Agar P and incubated at $37^{\circ} \mathrm{C}$ for $24-48 \mathrm{~h}$. Level of detection was of $10 \mathrm{CFU} \mathrm{ml} l^{-1}$. Counts obtained were compared with the American Dental Association standards for DUWS (i.e $\left.\leq 200 \mathrm{CFU} \mathrm{ml} \mathrm{H}^{-1}\right)(1)$.

\section{Test of antibiotic susceptibility}

Susceptibility to antibiotics was tested by the agar diffusion method (6), as recommended by the National Committee for Clinical Laboratory Standards- NCCLS (17). Only recognized antipseudomonal agents were evaluated, i.e., cephalosporins (ceftazidime), $\beta$-lactam- $\beta$-lactamase inhibitor combinations (ticarcilin/clavulanic acid, piperacillin/tazobactam), fluoroquinolones (ciprofloxacin), aztreonam and meropenem.

\section{RESULTS AND DISCUSSION}

From the one hundred and sixty water samples and two hundred dental clinic environment samples, $76(21.1 \%) P$. aeruginosa strains were isolated: $5(2.5 \%)$ from the environment and 71 (44.3\%) from the water samples. Among the environment isolates, one came from a headlight, one from an air/water syringe, two from high-speed drills and one from a low-speed drill. Although data on microbial contamination of surfaces or instruments from dental clinics are scarce, available research results have shown their extensive contamination by hepatitis B surface antigen (20) and hepatitis C virus (21); additional results have shown a high degree of contamination of trolley surfaces with Staphylococcus aureus and $\beta$ haemolytic Streptococcus (16).

Among water isolates, 12 came from tap water; 9 from ground tank, and 7 from bottle-fed water; these were jointly denominated 
the water reservoir; 21 isolates were from air/water syringes and 22 from high-speed drills. Table 1 shows the numbers of viable bacteria in water samples, found to be above the limit of $200 \mathrm{cfu} / \mathrm{ml}$ established by the American Dental Association (ADA) (1). Over $50 \%$ of the water samples analyzed had bacterial numbers above this standard. These figures agree with those reported by Walker et al. (30), showing that water supplies of $51 \%$ of the dental units in seven European Union countries exceeded the current ADA-recommendations for permissible levels of bacterial contamination. Table 1 also demonstrates that, from forty dental clinics of the city of Barretos, São Paulo, Brazil, in agreement with results reported by Souza-Gugelmin et $a l$. (29) the number of $P$. aeruginosa cells in the water coming from dental equipment was lower than that coming from the water syringe and high-speed drill.

Table 1. Total counts of bacteria $(\mathrm{cfu} / \mathrm{ml})$ in water samples from the 40 dental units of Barretos, São Paulo, Brazil, counted according to ADA recommendations, between January and July 2005.

\begin{tabular}{lcc}
\hline \multirow{2}{*}{ Site of collection } & \multicolumn{2}{c}{ Number in samples } \\
\cline { 2 - 3 } & $0-200 \mathrm{cfu} / \mathrm{ml}$ & $201-2000 \mathrm{cfu} / \mathrm{ml}$ \\
\hline Tap water & 25 & 15 \\
Reservoir & 17 & 23 \\
Air/water syringe & 12 & 28 \\
High-speed drill & 8 & 32 \\
\hline
\end{tabular}

Previous studies have shown extensive contamination of water in dental units, not only by water saprophytes, but also by some potentially pathogenic microorganisms like $P$. aeruginosa and Legionella pneumophila $(18,32)$. Biofilm formation along the walls of the fine bore waterlines seemed to be the primary factor responsible for such contamination $(26,33)$. The health hazard to patients of dental unit waterlines exposed to these high levels of bacteria remains a non-resolved issue $(11,16)$. While no apparent widespread nosocomial infections in dental patients have been directly attributed to the water used in dental treatment, concern does center on the exposure to potentially harmful microorganisms of immunocompromised patients or individuals receiving dental treatment while undergoing immunosuppressive chemotherapy $(15,26)$. Mills (15) reported two civil suits in which different plaintiffs claimed that their pathological conditions (bacterial endocarditis and a brain abscess, respectively) had resulted from exposure to contaminated water during dental treatment. Dental professionals are chronically exposed to pathogens in aerosols produced by high-speed handpieces and ultrasonic scalers (5). Costerton et al. (10) reported that biofilm fragments dispersed in aerosols can be inhaled or aspirated and that their lungs, colonized by these fragments, often showing no symptoms, but that stress may cause bacteria to proliferate, leading to acute infection.

Sheperd et al. (27) reported an unexpected finding by which approximately $80 \%$ of DUWLs tested harbored streptococci (Streptococcus sanguis, S. mutans/sobrinus. S. intermedius, S. mitis, S. salivarius), similar to those found in the dental plaque, mucosal tissues, tongue and saliva of the oral cavity. This observation indicates that contamination from patient-derived bacteria can occur at the functional end of water lines.

Pseudomonas spp are considered opportunistic pathogens, very commonly found in nature (soils, water, plants and animals), and water treatment systems, thus demonstrating their adaptation to environments with low nutrient concentration, and over a large temperature range, between 4 and $42^{\circ} \mathrm{C}$. Penna et al. (19) isolated 78 bacterial colonies showing a $32 \%$ prevalence of $P$. aeruginosa from samples of water directly taken from a public distribution water tank in the city of São Paulo, Brazil.

In the present study, $P$. aeruginosa was isolated from water samples collected at various sites (Table 2), that could be recovered from the oral cavity of approximately $4 \%$ of a population of healthy individuals (8). It could not be excluded that some of these bacteria were aspirated into the waterlines through a defective check valve, becoming able to colonize waterlines. The predominance of $P$. aeruginosa over other cultured bacterial species could be a consequence of their capacity to inhibit the growth of other bacteria in the waterlines (4).

In order to check the existence of a relationship between the type of setting where the water samples were collected and $P$. aeruginosa cell counts, the distribution of the total counts of bacteria was examined (Table 3). Supply of tap water occurred in $73.4 \%$ of dental care aid centers and in $75.0 \%$ of the public health dental system. The DUWS water quality was in accordance with ADA recommendations $(<200$ CFU. $\mathrm{ml}^{-1}$ ), thus highlighting the good quality of the water distributed

Table 2. Number of water samples contaminated with Pseudomonas aeruginosa among 40 dental units of Barretos, SP collected between January and July 2005.

\begin{tabular}{lcc}
\hline $\begin{array}{c}\text { Site of } \\
\text { collection }\end{array}$ & $\begin{array}{c}\text { Number of } \\
\text { contaminated samples }\end{array}$ & $\begin{array}{c}\text { Total } \\
\text { samples }\end{array}$ \\
\hline Tap water & 12 & 40 \\
Reservoir & 16 & 40 \\
Air/water syringe & 21 & 40 \\
High-speed drill & 22 & 40 \\
\hline Total & 71 & 160 \\
\hline
\end{tabular}


Table 3. Total counts of bacteria in cfu. $\mathrm{ml}^{-1}$ of water samples from different type of setting of dental units of Barretos, SP, counted according to ADA recommendations, between January and July 2005.

\begin{tabular}{lcccccc}
\hline & \multicolumn{5}{c}{ Type of setting } \\
\cline { 2 - 7 } Site of collection & \multicolumn{7}{c}{ Private dental system $(\mathrm{n}=17)$} & \multicolumn{2}{c}{ Dental care aid center $(\mathrm{n}=15)$} & Public health dental system $(\mathrm{n}=8)$ \\
\cline { 2 - 7 } & \multicolumn{2}{c}{ CFU (\%) } & \multicolumn{2}{c}{ CFU (\%) } & \multicolumn{2}{c}{ CFU (\%) } \\
\cline { 2 - 7 } & $0-200$ & $201-2000$ & $0-200$ & $201-2000$ & $0-200$ & $201-2000$ \\
\hline Tap water & $8(47.0)$ & $9(53.0)$ & $11(73.4)$ & $4(26.6)$ & $6(75.0)$ & $2(25.0)$ \\
Reservoir & $6(35.3)$ & $11(64.7)$ & $8(53.4)$ & $7(46.6)$ & $3(37.5)$ & $5(62.5)$ \\
Air/water syringe & $5(29.5)$ & $12(70.5)$ & $5(33.4)$ & $10(66.6)$ & $2(25.0)$ & $6(75.0)$ \\
High-speed drill & $3(17.6)$ & $14(82.4)$ & $4(26.6)$ & $11(73.4)$ & $1(12.5)$ & $7(87.5)$ \\
\hline
\end{tabular}

by the municipal water system. Nevertheless, the high percentage of cells counted in handpieces, also reported by Souza-Gugelmin et al. (29), should be a convincing indication of the large colonization of the DUWL units by opportunistic pathogens.

Nosocomial infections caused by Pseudomonas are frequently life threatening and difficult to control (22). Their antimicrobial susceptibility is limited to only a few drugs, and the emergence of resistance during therapy against initially susceptible strains occurs at relatively high frequency (9). Due to the increasing use of broad-spectrum antibiotics, incidence of multidrug resistant $P$. aeruginos $a$ strains is increasing, turning the clinical treatment of these infections an ever more challenging problem (13). Fig. 1 shows the pattern of susceptibility of $76 P$. aeruginosa isolates to six antimicrobial drugs commonly used for the treatment of infections caused by

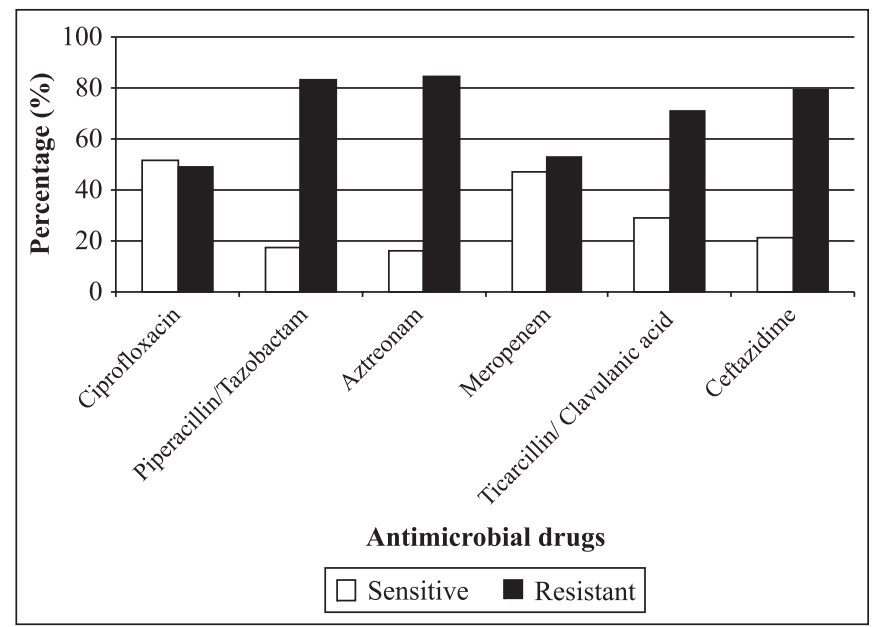

Figure 1. Antimicrobial susceptibility patterns in Pseudomonas aeruginosa isolated from dental units in Barretos, SP, between January and July 2005. these bacteria. The frequency of resistance is higher than that reported by Eldere (12) for Belgian isolates, but similar to those reported by Jung et al. (13) in the USA, both gathered at hospital settings. A high level of resistance of isolates from the intensive care unit of a Brazilian hospital has also been reported by Severino and Magalhães (25). Yet, to the best of our knowledge, data on antimicrobial resistance among $P$. aeruginosa isolates from dental clinics in Brazil has been scarce.

Horizontal gene transfer among clinical isolates showing antibiotic resistance evoked by strong antibiotic selection pressure has resulted in a widespread distribution of multidrugresistant strains (MDR). For P. aeruginosa, such resistance is primarily responsible for nosocomial infections in intensive care units (3); however, the possibility of its dissemination in a dental clinic by cross contamination involving patients and dental

Table 4. Patterns of drug resistance and phenotypes among multidrug-resistant Pseudomonas aeruginosa isolates from dental units.

\begin{tabular}{cl}
\hline \multicolumn{1}{c}{ Patterns } & \multicolumn{1}{c}{ Phenotypes } \\
\hline Resistant to 2 drugs (8)* & Cip-pit** \\
& Cip-atm \\
& Cip-mpm \\
& Cip-tac \\
& Cip-caz \\
& Cip-pit-atm \\
Resistant to 3 drugs (15) & Pit-mpm-caz \\
& Mpm-atm-tac \\
Resistant to 4 drugs (12) & Cip-pit-atm-mpm \\
Resistant to 5 drugs (16) & Cip-pit-atm-mpm-tac \\
Resistant to 6 drugs (20) & Cip-pit-atm-mpm-tac-caz \\
\hline
\end{tabular}

*-number of isolates;

**- cip-ciprofloxacin; pit-piperacillin/tazobactam; atm-aztreonam; mpm-meropenem; tac- ticarcillin/clavulanic acid; caz-ceftazidime. 
office teams exists, and is becoming a growing problem worldwide, posing serious therapeutic challenges.

$P$. aeruginosa isolates were considered multidrug resistant when they were resistant to at least three of the following drugs: imipenem/meropenem, ceftazidime, cyprofloxacin and tobramycin. Such resistance, relatively common among nosocomial isolates, is the highest in Latin America (8.0\%), lower in Europe (5.0\%) and even lower in North America and the AsianPacific regions $(<2.0 \%)(24)$. Table 4 shows the distribution of phenotypes resistant to three or more antimicrobial drugs of the $P$. aeruginosa isolates recovered in the present study. Using other authors criteria to characterize multidrug resistance in $P$. aeruginosa, only the twenty isolates resistant to all drugs tested were classified as multidrug resistant strains.

$P$. aeruginosa remains one of the most important and difficult to treat pathogens commonly found in DUWL. Therefore, practical methods for controlling microbial contamination are urgently needed.

\section{RESUMO}

\section{Isolamento de cepas de Pseudomonas aeruginosa provenientes do meio ambiente e de equipos dentarios em clinicas dentarias em Barretos, São Paulo, Brasil; analises da susceptibilidade das cepas a drogas antimicrobianas}

Uma ampla variedade de patógenos oportunistas tem sido detectadas nos tubos de alimentação de água dos equipos odontológicos, particularmente no biofilme formado na superfície do tubo. Entre os patógenos oportunistas encontrados nos tubos de água, Pseudomonas aeruginosa é reconhecida como uma das principais causadoras de infecções nosocomiais. Foram coletadas 160 amostras de água e 200 amostras de fomites em quarenta clinicas odontológicas na cidade de Barretos, São Paulo, Brasil, durante o período de Janeiro a Julho de 2005. Setenta e seis cepas de $P$. aeruginosa, isoladas a partir dos fomites ( 5 cepas) e das amostras de água (71 cepas), foram analisadas quanto à susceptibilidade à seis drogas antimicrobianas freqüentemente utilizadas para o tratamento de infecções provocadas por $P$. aeruginosa. As principais suscetibilidades observadas foram para a ciprofloxacina, seguida pelo meropenem. A necessidade de um mecanismo efetivo para reduzir a contaminação bacteriana dentro dos tubos de alimentação de água dos equipos odontológicos foi enfatizada, e o risco da exposição ocupacional e infecção cruzada na prática odontológica, em especial quando causada por patógenos oportunistas como a $P$. aeruginosa foi realçado.

Palavras-chave: Pseudomonas aeruginosa, equipo odontológico, linha de água, patógeno oportunista, resistência antimicrobiana, biofilme.

\section{REFERENCES}

1. American Dental Association Council on Scientific Affairs (1999). Dental unit waterlines: approaching the year 2000. J. Am. Dent. Assoc., 130, 653-664.

2. APHA-AWWA-WEF (1998). Standard Methods for examination of water and wastewater. American Public Health Association, American Water Works Association, Water environ. Fed $20^{\text {th }}$ edition 9, 29-30.

3. Arruda, E.A.; Marinho, J.S.; Boulos, M.; Sinto, S.J.; Caiaffa, H.H.; Mendes, C.M.; Oplusstil, C.P.; Sader, H.; Levy, C.E.; Levin, A.S (1999). Nosocomial infections caused by multiresistant Pseudomonas aeruginosa. Infect. Control Hosp. Epidemiol., 20, 620-623.

4. Barbeau, J.; Tanguay, R.; Faucher, E.; Avezard, C.; Trudel, L.; Cote, L.; Prevost, A.P. (1996). Multiparametric analysis of waterline contamination in dental units. Appl. Environ. Microbiol., 62, 3954 3959.

5. Barbeau, J.; Gauthier, C.; Payment, P. (1998). Biofilms, infectious agents and dental unit waterlines: a review. Can. J. Microbiol., 44, 1019-1028.

6. Bauer, A.W.; Kirby, W.M.M.; Sherris, J.C. (1966). Antibiotics susceptibility testing by a standardized single disk method. Am. $J$. Clin. Pathol., 45, 493-496.

7. Beierie, J.W. (1993). Dental operatory water lines. Calif. Dent. Assoc. J., 21, 13-15.

8. Botzenhardt, K.; Puhr, O.F.; Doring, G. (1987). Pseudomonas aeruginosa in the oral cavity of healthy adults: frequency and age distribution. Zentralbl. Bakteriol. Mikrobiol. Hyg. Abt. Orig. B., 180, 471-479.

9. Carmeli, Y.; Troillet, N.; Etiopoulos, G.M. (1999). Emergence of antibiotic-resistant Pseudomonas aeruginosa: comparison of risk associated with different anti-pseudomonal agents. Antmicrob. Agents Chemother., 43, 1379-1382.

10. Costerton, J.W.; Stewart, P.S.; Greenberg, E.P. (1999). Bacterial biofilms: A common cause of persistent infections. Science, 284, 1318-1322.

11. Depaola, L.G.; Mangan, D.; Mills, S.E.; Costerton, W.; Barbeau, J.; Shearer, B.; Bartlett, J. (2002). A review of the science regarding dental unit waterlines. JADA, 133, 1199-1206.

12. Eldere, J.V. (2003). Multicentre susveillance of Pseudomonas aeruginosa susceptibility patterns in nosocomial infections. $J$. Antimicrob. Chemother., 51, 347-352.

13. Jung, R.; Fish, D.N.; Obritsch, M.D.; MacLaren, R. (2004). Surveillance of multi-drug resistant Pseudomonas aeruginosa in an urban tertiary-care teaching hospital. J. Hosp. Infect., 57, 105-111.

14. Martin, M.V. (1987). The significance of the bacterial contamination of dental unit water systems. Br. Dent. J., 163, 152-153.

15. Mills, S.E. (2000). The dental unit waterline controversy: defusing the myths, defining the solutions. JADA, 131, 1427-1441.

16. Monarca, S.; Grottolo, M.; Renzi, D.; Paganelli, C.; Sapelli, P.; Zerbini, I.; Nardi, G. (2000). Evaluation of environmental bacterial contamination and procedures to control cross infection in a sample of Italian dental surgeries. Occup. Environ. Med., 57: 721-726.

17. National Committee for Clinical Laboratory Standards. (1998) Performance Standards for Antimicrobial Testing, NCCLS, Wayne, PA.

18. Pankhurst, C.L.; Philpott-Howard, J.N. (1993). The microbiological quality of water in dental chair units. J. Hosp. Infect. 23,167-174.

19. Penna, V.T.C.; Martins, S.A.M.; Mazola, P.G. (2002). Identification of bacteria in drinking and purified water during the monitoring of a typical water purification system. BMC Public Health, 2, 13-23.

20. Piazza, M.; Guadagnino, V.; Piciotto, I. (1987). Contamination by hepatitis B surface antigen in dental surgeries. Br. Med. J., 295, 473474. 
21. Piazza, M.; Borgia, G.; Picciotto, I. (1995). Detection of hepatitis C virus-RNA by polymerase chain reaction in dental surgeries. J. Med. Virol., 45, 40-42.

22. Rello, J.; Rue, M.; Jubert, P. (1997). Survival in patients with nosocomial pneumonia: impact of the severity of illness and the etiologic agent. Crit. Care Med., 25, 1862-1867.

23. Robert, M.; Barbeau, J.; Prevost, A.P.; Charland, R. (1994). Dental unit water lines; a propitious environment for bacterial colonization. J. Dent. Quebec, 31, 205-211.

24. Rossolini, G.M.; Mantengoli, E. (2005). Treatment and control of severe infections caused by multiresistant Pseudomonas aeruginosa. Clin. Microbiol. Infect., 11, 17-32.

25. Severino, P.; Magalhães, V.D. (2002). The role of integrons in the dissemination of antibiotic resistance among clinical isolates of Pseudomonas aeruginosa from an intensive care unit in Brazil. Res. Microbiol., 153, 221-226.

26. Shearer, B.G. (1996). Biofilm and the dental office. JADA, 127, 181-189.

27. Sheperd, P.A.; Shojaei, M.A.; Eleazer, P.D.; van Stewart, A.; Staat, R.H. (2001). Clearance of biofilmes from dental unit waterlines through the use of hydroperoxide ion-phase transfer catalysts. Quintessense Int., 32, 755-761.
28. Shiraishi, T.; Nakagawa, Y. (1993). Review of disinfectant susceptibility of bacteria isolated in hospitals to commonly used disinfectants. Postgra. Med. J., 69 (Suppl. 3), S70-S77.

29. Souza-Gugelmin, M.C.M.; Lima, C.D.T.; Lima, S.N.M.; Mian, H.; Ito, I.Y. (2003). Microbial Contamination in Dental Unit Waterlines. Braz. Dent. J., 14, 55-57

30. Walker, J.T.; Bradshaw, D.J.; Finney, M.; Fulford, M.R.; Frandsen, E.; Ostergaard, E.; Cate, J.M.; Moorer, W.R.; Schel, A.J.; Mavridou, A.; Kamma, J.J.; Mandilara, G.; Stosser, L.; Kneist, S.; Araujo, R.; Contreras, N.; Goroncy-Bermes, P.; Oõ Mullane, D.; Burke, F.; Forde, A.; Õ Sullivan, M.; Marsh, P.D. (2004). Microbial evaluation of dental unit water systems in general dental practice in Europe. Eur. J. Oral Sci., 112, 412-418.

31. Whitehouse, R.L.S.; Peters, E.; Lizotte, J.; Lilge, C. (1991). Influence of biofilms on microbial contamination in dental unit water. J. Dent., 19, 290-295.

32. Williams, J.F.; Johnston, A.M.; Johnson, B.; Huntington, M.K.; Mackenzie, C.D. (1993). Microbial contamination of dental unit waterlines: prevalence, intensity and microbiological characteristics. JADA, 124, 59-65.

33. Williams, H.N.; Baer, M.L.; Kelley, J.I. (1995). Contribution of biofilm bacteria to the contamination of the dental unit water supply. $J A D A, 126,1255-1260$. 